\title{
Erythrocyte glucose-6-phosphate dehydrogenase from Brazilian opossum Didelphis marsupialis
}

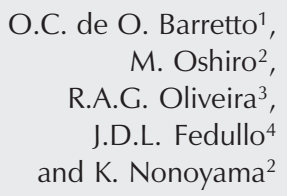

\author{
${ }^{1}$ LIM-23, Faculdade de Medicina, Universidade de São Paulo, São Paulo, SP, Brasil \\ ${ }^{2}$ Instituto Adolfo Lutz, São Paulo, SP, Brasil \\ ${ }^{3}$ Divisão de Hematologia, Universidade Federal of Maranhão, São Luis, MA, Brasil \\ ${ }^{4}$ Divisão de Veterinária, Fundação Parque Zoológico de São Paulo, \\ São Paulo, SP, Brasil
}

\section{Correspondence \\ O.C. de O. Barretto \\ Av. Pedroso de Morais, 70/101 \\ 05420-000 São Paulo, SP \\ Brasil \\ Fax: +55-11-3813-6259 \\ E-mail: ocdobarr@usp.br}

Received March 9, 2005

Accepted January 30, 2006

\begin{abstract}
In a comparative study of erythrocyte metabolism of vertebrates, the specific activity of glucose-6-phosphate dehydrogenase (G6PD) of the Brazilian opossum Didelphis marsupialis in a hemolysate was shown to be high, $207 \pm 38 \mathrm{IU} \mathrm{g}^{-1} \mathrm{Hb}^{-1} \mathrm{~min}^{-1}$ at $37^{\circ} \mathrm{C}$, compared to the human erythrocyte activity of $12 \pm 2 \mathrm{IU} \mathrm{g}^{-1} \mathrm{Hb}^{-1} \mathrm{~min}^{-1}$ at $37^{\circ} \mathrm{C}$. The apparent high specific activity of the mixture led us to investigate the physicochemical properties of the opossum enzyme. We report that reduced glutathione (GSH) in the erythrocytes was only $50 \%$ higher than in human erythrocytes, a value lower than expected from the high G6PD activity since GSH is maintained in a reduced state by G6PD activity. The molecular mass, determined by G-200 Sephadex column chromatography at $\mathrm{pH} 8.0$, was $265 \mathrm{kDa}$, which is essentially the same as that of human G6PD (260 kDa). The Michaelis-Menten constants $\left(K_{\mathrm{m}}: 55 \mu \mathrm{M}\right)$ for glucose-6-phosphate and nicotinamide adenine dinucleotide phosphate $\left(K_{\mathrm{m}}: 3.3 \mu \mathrm{M}\right)$ were similar to those of the human enzyme ( $K_{\mathrm{m}}: 50-70$ and $K_{\mathrm{m}}: 2.9-4.4$, respectively). A 450 -fold purification of the opossum enzyme was achieved and the specific activity of the purified enzyme, $90 \mathrm{IU} / \mathrm{mg}$ protein, was actually lower than the $150 \mathrm{IU} / \mathrm{mg}$ protein observed for human G6PD. We conclude that G6PD after purification from the hemolysate of $D$. marsupialis does not have a high specific activity. Thus, it is quite probable that the red cell hyperactivity reported may be explained by increased synthesis of G6PD molecules per unit of hemoglobin or to reduced inactivation in the RBC hemolysate.
\end{abstract}

Key words

- Erythrocyte glucose-6-

phosphate dehydrogenase

- Didelphis marsupialis

- Erythrocyte glutathione
Glucose-6-phosphate dehydrogenase (G6PD) is a key enzyme in the redox metabolism of most cells, and particularly of red cells, which are highly susceptible to oxidative damage. During a comparative study of red cell metabolism in vertebrates, we have observed serendipitously that G6PD activity is very high in a red cell hemolysate of the South-American opossum Didelphis marsupialis. It was $207 \pm 38 \mathrm{IU} \mathrm{g}^{-1} \mathrm{Hb}^{-1} \mathrm{~min}^{-1}$ at $37^{\circ} \mathrm{C}$, compared to human enzyme in a hemolysate, $12 \pm 2 \mathrm{IU} \mathrm{g}^{-1} \mathrm{Hb}^{-1} \mathrm{~min}^{-1}$ at $37^{\circ} \mathrm{C}$. 
Table 1. Comparison of the biochemical characteristics of Didelphis marsupialis red cell glucose-6-phosphate dehydrogenase with the human enzyme G6PD B.

\begin{tabular}{lll}
\hline & $\begin{array}{c}\text { D. marsupialis } \\
(\mathrm{N}=2)\end{array}$ & $\begin{array}{c}\text { Human G6PD B } \\
(\text { Ref. 5) }\end{array}$ \\
\hline Activity $\left(\mathrm{IU} \mathrm{g} \mathrm{Hb}^{-1} \mathrm{~min}^{-1}\right)(\mathrm{N}=5)$ & $207 \pm 38$ & $12.1 \pm 2$ \\
Hemolysate specific activity $\left(\mathrm{mg}^{-1}\right.$ protein) & 0.2 & $0.012 \pm 0.002^{\mathrm{a}}$ \\
Final specific ativity of purified prep. & 90 & $150($ Ref. 9) \\
Electrophoretic mobility & $125 \%$ & $100 \%$ \\
$K_{\mathrm{m}}$ for $\mathrm{G} 6 \mathrm{P}(\mu \mathrm{M})$ & 55 & $50-70$ \\
$K_{\mathrm{m}}$ for $\mathrm{NADP}(\mu \mathrm{M})$ & 3.3 & $2.9-4.4$ \\
$K_{\mathrm{i}}$ for NADPH $(\mu \mathrm{M})$ & 32 & $7.6-30$ \\
Deamino-NADP utilization $(\%$ of NADP) & $90 \%$ & $55-60 \%$ \\
2-deoxy-G6P utilization $(\%$ of G6P) & $8.5 \%$ & $0-4 \%$ \\
Thermal stability at $46^{\circ} \mathrm{C}$ & like human & $(\text { Ref. } 5)^{\mathrm{c}}$ \\
Optimum pH & 8.5 & 8.5 \\
Glutathione, reduced $(\mu \mathrm{M} / \mathrm{g} \mathrm{Hb})$ & 9.8 & $6.6 \pm 1$ (Ref. 3) \\
Molecular weight $($ Ref. 8$)$ & $265 \mathrm{kDa}$ & $260 \mathrm{kDa}$ (Ref. 8)
\end{tabular}

G6P = glucose-6-phosphate; NADP = nicotinamide adenine dinucleotide phosphate; $\mathrm{NADPH}=$ reduced form of NADP; $K_{\mathrm{m}}=$ Michaellis Menten constant; $K_{\mathrm{i}}=$ inhibition constant.

${ }^{\mathrm{a}} \mathrm{Ca} .95 \%$ of hemolysate proteins are hemoglobins. ${ }^{\mathrm{b}}$ Electrophoresis of hemolysate enzyme, in cellulose acetate; conditions in Ref. 7. CHuman G6PD B thermal stability at $46^{\circ} \mathrm{C}$ : $90 \%$ of initial activity after $20 \mathrm{~min}$ of incubation, $75-90 \%$ after $40 \mathrm{~min}$, and $65-85 \%$ after $60 \mathrm{~min}$.

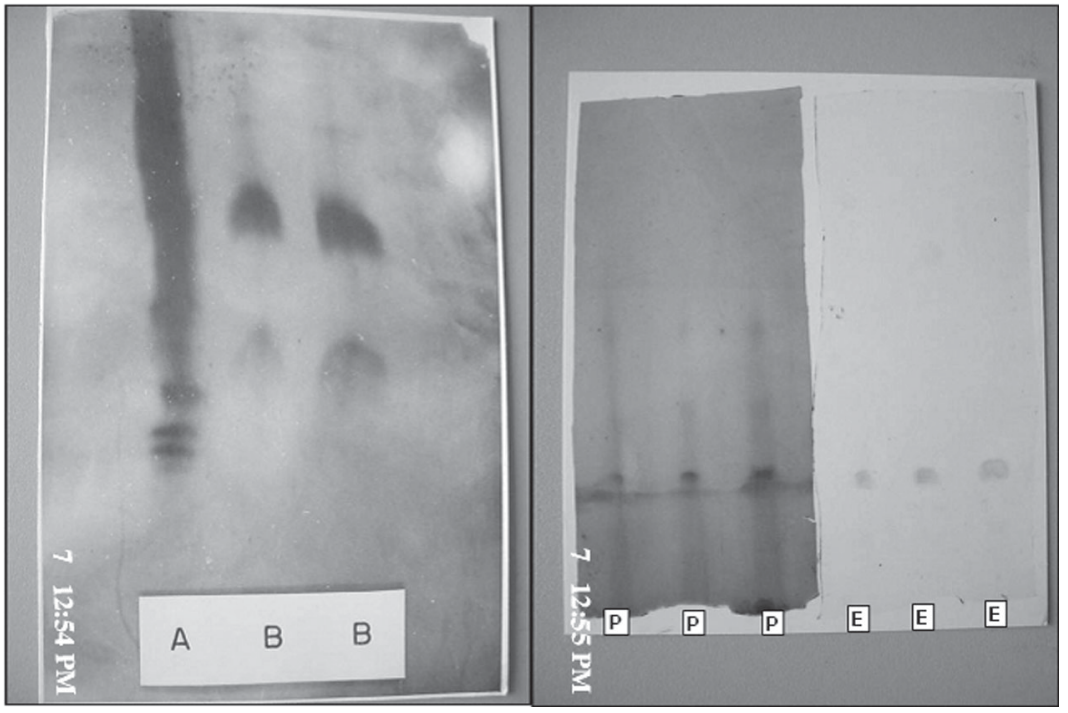

Figure 1. Purification of opposum G6PD from crude hemolysate exhibiting as specific activity of $0.2 \mathrm{IU} / \mathrm{mg}$ protein (hemoglobin). Left - Lane A, Last multi-step ammonium sulfate preparation described in Ref. 5 (in which both hemoglobins and 6-phosphogluconate dehydrogenase were discarded), previously dialysed against $5 \mathrm{mM}$ Tris- $\mathrm{HCl}, \mathrm{pH}$, presenting $12 \mathrm{lU} / \mathrm{mg}$ protein (60-fold purification), submitted to denatured $10 \%$ polyacrylamide gel electrophoresis (SDS-PAGE), 50 volts for $16 \mathrm{~h}$, stained for protein. Lane B, ADP. Sepharose-4B preparation submitted to denatured SDS-PAGE presenting $70 \mathrm{IU} / \mathrm{mg}$ protein (350-fold purification), stained for proteins. Right - Lanes $P$, final DE-Sephadex preparation presenting $90 \mathrm{IU} / \mathrm{mg}$ protein (450-fold purification), submitted to non-denatured $10 \%$ PAGE, 50 volts for $4 \mathrm{~h}$ (Ref. 7), stained for proteins showing one dark band and a slight smear. Lanes $E$, the same final DE-Sephadex purified preparation depicting one band stained for enzyme activity at the same position of the dark band stained for proteins at lane $P$.
A similar relationship of red cell G6PD activity to hemoglobin has also been reported for another South-American opossum, Didelphis aurita (1) and in other Australian marsupials (2), although not as high as in $D$. marsupialis.

This high specific activity in terms of hemoglobin content of the hemolysate raised some questions, e.g.: 1) Why is this activity ratio so high? 2) Is the enzyme a very active molecule, with high affinity for its substrates? 3 ) Or is the molecule ratio of G6PD to hemoglobin higher in D. marsupialis than in humans because of increased synthesis or reduced inactivation.

Since G6PD catalyzes the metabolic step in the deviation of the pentoses in which nicotinamide adenosine dinucleotide phosphate (NADP) is converted to its reduced form (NADPH), NADPH is necessary to maintain glutathione in its reduced form $(\mathrm{GSH})$, and is a very important reducing nucleotide in red cell redox metabolism. The concentration of $D$. marsupialis red blood cell GSH would be expected to be very high compared to the human enzyme, but this was not the case since the opposum GSH is only $50 \%$ higher than the human GSH (Table 1). However, it is possible that the conversion rate of the oxidized form of glutathione (GSSG) to reduced glutathione may be increased, since high levels of NADPH are expected from high G6PD activity.

The erythrocyte G6PD of the opossum was purified and its properties were compared with those of the normal human enzyme G6PD B (Gd B). Male specimens were identified by an experienced Brazilian zoologist. Blood was collected in ACD medium, washed three times in saline at 5,000 $\mathrm{g}$ at $4^{\circ} \mathrm{C}$, and the packed red cells were lysed $1: 20$ in a hemolyzing solution, and centrifuged at $10,000 \mathrm{~g}$.

The supernatant was assayed to determine the G6PD activity at $37^{\circ} \mathrm{C}$ according to Beutler (3) and the enzyme was partially purified according to the methods employed 
for human G6PD $(4,5)$. This preparation was used for enzyme characterization at $25^{\circ} \mathrm{C}$ and for the determination of the MichaelisMenten constants for its substrate glucose6-phosphate (G6P) and the NADP co-enzyme and of the $K_{\mathrm{i}}$ inhibition constant for $\mathrm{NADPH}$. Electrophoresis was carried out in acetate cellulose, $\mathrm{pH}$ 8.0, and optimum $\mathrm{pH}$ and thermostability were determined.

The data in Table 1 suggest that the kinetic properties of the Didelphis enzyme are very similar to those of the human enzyme, with a $K_{\mathrm{m}}$ of the order of $55 \mu \mathrm{M}$ for G6P and of $3.3 \mu \mathrm{M}$ for NADP. This fact rules out the possibility of an enzyme with high affinity for its substrates. The partially purified enzyme was then further purified until an almost homogeneous state by the method of Descalzi-Cancedda et al. (6), which is based on the affinity of 2',5'-ADP-Sepharose-4B for the enzymes which present NADP as coenzyme. G6PD was eluted with $0.2 \mathrm{mM}$ NADP and the fractions eluted from the ADP-Sepharose column with higher specific activities were pooled and one IU was applied to one $0.4 \times 8 \mathrm{~cm}$ DE-Sephadex column equilibrated with $50 \mathrm{mM}$ Na phosphate buffer, $\mathrm{pH} 7.5,0.1 \mathrm{mM}$ EDTA and $0.2 \%$ beta-mercaptoethanol. A $50-400 \mathrm{mM}$ $\mathrm{KCl}$ gradient was employed to elute G6PD. The effluent was pooled and the specific activity of G6PD was shown to be $90 \mathrm{IU} / \mathrm{mg}$ protein. Starting from the initial red cell specific activity of $0.2 \mathrm{IU} / \mathrm{mg}$ protein (hemoglobin), the last purification step of the DE-Sephadex preparation reached 90 IU/ mg protein, affording a final 450-fold purification. In order to evaluate the homogenity of purification of this final preparation, the preparation was submitted to non-denaturing $7 \%$ polyacrylamide gel vertical electrophoresis (7), and in the same gel, separate lanes were stained for protein with $\mathrm{Coo}-$ massie blue, and parallel lanes were stained for G6PD activity. The lanes stained for proteins showed a dark band and a slight smear, and the lanes stained for enzyme activity revealed a band juxtaposed to the dark protein band (Figure 1), showing that the greater part of the enzyme activity was detected in the same position as the dark protein band. The molecular mass of G6PD was determined by G-200 Sephadex column chromatography at $\mathrm{pH} 8.0$ and was found to be $265 \mathrm{kDa}$, which is essentially the same as that of the human G6PD, $260 \mathrm{kDa}(8)$.

The present data suggest that the high ratio of hemolysate activity of erythrocyte G6PD to hemoglobin observed in hemolysates of D. marsupialis erythrocytes is not due to a high specific activity of the enzyme, which was $90 \mathrm{IU} / \mathrm{mg}$ protein, indeed lower than the $150 \mathrm{IU} / \mathrm{mg}$ protein reported for the human enzyme (9). Moreover, its physicochemical properties and mostly the affinity for its substrates led us to conclude that $D$. marsupialis red cell G6PD is not a very active enzyme.

The present data suggest that there is a higher synthetic rate of G6PD copies per red cell or that there is a reduced G6PD inactivation in the hemolysate.

\section{References}

1. Nobrega FG, Maia JC, Colli W et al. (1970). Heterogeneity of erythrocyte glucose-6-phosphate dehydrogenase (G6PD, E.C. 1.1.1.49) activity and electrophoretic patterns among representatives of different classes of vertebrates. Comparative Biochemistry and Physiology, 33: 191-199.

2. Parkinson AL, Whittington AT, Spencer PB et al. (1995). Comparative erythrocyte metabolism in marsupials and monotremes. Comparative Biochemistry and Physiology. Part C, Pharmacology, Toxi- cology and Endocrinology, 110: 261-265.

3. Beutler E (1984). Red Cell Metabolism. A Manual of Biochemical Methods. Grune \& Stratton Inc., Orlando, New York.

4. WHO Scientific Group (1967). Standardization of procedures of the study of glucose-6-phosphate dehydrogenase. World Health Organization Technical Report Series, 366: 1-53.

5. Beutler E, Mathai CK \& Smith JE (1968). Biochemical variants of glucose-6-phosphate dehydrogenase giving rise to congenital 
nonspherocytic hemolytic disease. Blood, 31: 131-150.

6. Descalzi-Cancedda F, Caruso C, Romano M et al. (1984). Amino acid sequence of the carboxy-terminal end of human erythrocyte glucose-6-phosphate dehydrogenase. Biochemical and Biophysical Research Communications, 118: 332-338.

7. Nakatsuji T \& Miwa S (1981). A new improved electrophoretic method of glucose-6-phosphate dehydrogenase with discontinuous buffer and gel system. Analytical Biochemistry, 112: 52-54.

8. Cohen P \& Rosemeyer MA (1968). The molecular weight and subunit structure of glucose-6-phosphate dehydrogenase from human erythrocytes. FEBS Letters, 1: 147-149.

9. Town M, Bautista JM, Mason PJ et al. (1992). Both mutations in G6. Human Molecular Genetics, 1: 171-174. 